\title{
STUDY OF FRESH PROPERTIES OF UHPC USING VOLUME PASTE APPROACH
}

\author{
Santhosh K ${ }^{1}$, Savithri Karanth ${ }^{2}$, Manoj $V^{3}$ \\ ${ }^{1}$ Post Graduate Student, Global Academy of Technology, RR Nagar, Bangalore, Karnataka, India \\ ${ }^{2}$ Department of Civil Engineering, Global Academy of Technology, Bangalore, India \\ ${ }^{3}$ Post Graduate Student, Global Academy of Technology, RR Nagar, Bangalore, Karnataka, India
}

\begin{abstract}
The packing density approach is used to calculate the UHPC mix required for the study. The Particle Packing Approach is adopted to minimize the volume of cement paste by minimizing the volume of voids in concrete. The present experimental study is on the rheological behaviour of four design mixes UHPC in which two mixes are with coarse aggregates of $12.5 \mathrm{~mm}$ downsize and other two mixes are without coarse aggregates. The behaviour in fresh state of each mix is studied by varying the paste content. The two mineral admixtures used in all the mixes are $10 \%$ micro silica and $5 \%$ metakaolin replacing cement by weight. Manufactured Sand (M-Sand) and quartz sand are used as fine aggregates. Quartz sands consist of particle size ranging from 150micron to 45 micron. $1 \%$ to $2 \%$ Steel fibres are used in all the mixes to resist shrinkage cracks in concrete mix. Paste content for each water binder ratio $(0.3,0.26,0.22)$ is calculated using particle packing mix approach The fresh properties of UHPC Slump test, J ring, L-box test, V-funnel test and U-box tests are conducted as per EFNARC 2005 for different paste content. Corresponding 3 day and 28 day of compressive strength for the each paste content is determined and achieve compressive strength of 119.5MPa for mix without coarse aggregate and 105.36 mix with coarse aggregate.
\end{abstract}

Keywords: Packing Density, Paste Content, Rheological Behaviour, Compressive Strength.

$* * *$

\section{INTRODUCTION}

Now a day's concrete is second highest material consumed by human after water and food. Use of advanced materials in the concrete led to the development of Ultra high performance concrete. It is effectively used in the high raise building, nuclear power plant and infrastructure. Use of UHPC reduces the self weight and reduces the total load.

The UHPC consists of combinations of different mineral admixtures, chemical admixtures which help in adopting low water binder ratio, fine aggregates, with or without well-graded coarse aggregates and discrete fiber reinforcement. The compressive strength of UHPC is greater than $120 \mathrm{MPa}$ and tensile strength is greater than $5 \mathrm{MPa}$. UHPC is not a self compacting concrete but it shows the rheological properties namely fillability, flowability and segregation resistance of Self Compacting Concrete.

This paper is on the rheological behaviour of two design mixes of UHPC in which one mix with coarse aggregates of $12.5 \mathrm{~mm}$ downsize and other mix without coarse aggregates. The two mineral admixtures used in all the mixes are $10 \%$ micro silica and 5\% metakaolin replacing cement by weight. Manufactured Sand (M-Sand) and quartz sand are used as fine aggregates. Quartz sands consist of particle size ranging from 150 micron to 45 micron. $1 \%$ to $2 \%$ Steel fibres are used in all the mixes to resist shrinkage cracks in concrete mix.

Paste content for each water binder ratio $(0.3,0.26,0.22)$ is calculated using particle packing mix approach. The behaviour in fresh state of each mix is studied with corresponding paste content. The fresh properties of UHPC Slump test, J ring, L-box test \& V-funnel test are conducted as per EFNARC 2005. The fresh behaviour of UHPC such as passing ability, filling ability of fresh UHPC is evaluated. The corresponding 3 day and 28 day compressive strength for the each paste content is determined.

\section{MATERALS}

\subsection{Cement}

53 grade of ordinary Portland cement confirming to IS: 12269 - 1987. It has the specific gravity of 3.15 .

\subsection{Micro Silica}

It is the waste product silicon metal or ferrosilicon alloy industries. It mainly consists of $\mathrm{SiO}_{2}$ about 93.5\%. The specific gravity of micro silica is 2.2 . Chemical constituents are shown in Table 2.1

Table 2.1 Chemical Constituents of Micro Silica

\begin{tabular}{|l|l|}
\hline $\begin{array}{l}5 \mathrm{Name} \text { of the } \\
\text { Composition }\end{array}$ & $\begin{array}{l}\text { Percentage } \\
\text { Contents }\end{array}$ \\
\hline $\mathrm{SiO}_{2}$ & $93.58 \%$ \\
\hline $\mathrm{Fe}_{2} \mathrm{O}_{3}$ & $0.25 \%$ \\
\hline $\mathrm{Al}_{2} \mathrm{O}_{3}$ & $0.20 \%$ \\
\hline $\mathrm{CaO}$ & $0.38 \%$ \\
\hline $\mathrm{MgO}$ & $0.49 \%$ \\
\hline others & $5.11 \%$ \\
\hline
\end{tabular}




\subsection{Metakoaline}

Metakaolin is produced by heating kaolin to a temperature of 1200 to $1650^{\circ} \mathrm{F}$. It has specific gravity of 2.56 and surface area of 8 to $25 \mathrm{~m}^{2} / \mathrm{gm}$. Average particle size is less than $2.5 \mu \mathrm{m}$. Chemical constituents of metakoaline shown in Table 2.2.

Table 2.2 Chemical Constituents of Metakaoline.

\begin{tabular}{|l|l|}
\hline $\begin{array}{l}\text { Name of the } \\
\text { Composition }\end{array}$ & $\begin{array}{l}\text { Percentage of } \\
\text { Contents }\end{array}$ \\
\hline $\mathrm{SiO}_{2}$ & $52 \%$ \\
\hline $\mathrm{Fe}_{2} \mathrm{O}_{3}$ & $1.70 \%$ \\
\hline $\mathrm{Al}_{2} \mathrm{O}_{3}$ & $42 \%$ \\
\hline $\mathrm{CaO}$ & $0.50 \%$ \\
\hline $\mathrm{MgO}$ & $0.50 \%$ \\
\hline others & $3.51 \%$ \\
\hline
\end{tabular}

\subsection{Quartz Sand}

It is made up of a lattice of silica $\left(\mathrm{SiO}_{2}\right)$ tetrahedral. The hardness of the quartz sand is 7 as per Mohs scale and its density is $2.65 \mathrm{~g} / \mathrm{cm}^{3}$. There are 3 different sizes of quartz sand are used in this experiment work. They are 60mesh, 100 mesh and 200mesh.

\subsection{Fine Aggregate}

The $\mathrm{M}$ sand is used as a fine aggregate conforming to the requirements of IS: 383-1970. It has a specific gravity of 2.63 and water absorption is about $3.5 \%$.

\subsection{Coarse Aggregate}

The $12 \mathrm{~mm}$ down size coarse aggregates conforming to the requirements of IS: 383-1970 are used in this experimental work. Coarse aggregate has rough texture and angular shape, so which is more suitable for UHPC to gain the strength.

\subsection{Steel Fibres}

A hooked type steel fibres are used in this experimental work. Length of the steel fibres is $30 \mathrm{~mm}$ and diameter is $0.5 \mathrm{~mm}$, aspect ratio is 60 . The specific gravity of the hooked steel fibres is 7.86 and it has tensile strength of $1100 \mathrm{MPa}$.

\subsection{Chemical Admixtures}

Talrakplast PC is used as a chemical admixture. It is a P C based new generation Hyper Plasticizer specially designed for Self Compacting Concrete. Characteristics of PC: DNY M70 of PCE based super plasticizer; water reduction capacity is about $40 \%$. Specific Gravity of this admixture is 1.10

\subsection{Water}

Normal tap water is for mixing and curing all the concrete specimens, $\mathrm{Ph}$ is almost neutral.

\section{EXPERIMENTAL WORK}

\subsection{Particle Packing Density Mix Approach}

There are non codal references for the mix design of higher grade concrete. Therefore mix design can be done by using particle packing density mix approach. Particle Packing gives indirect measurement of geometry of the concrete mass and also gives the cement paste to be required to fill the void content in present in the concrete. To achieve the optimized particle packing density, particle is selected in such a way that, smaller size particle fill up the voids between the larger particle and so on. The voids between the aggregate particles are filled by the cement paste and excess of paste will form a thin coating around each aggregate present in the mix.

In order to achieve optimized particle packing density fine sand is sieved in to different size particles, such as particles passing through $1.18 \mathrm{~mm}, 0.6 \mathrm{~mm}, 0.3 \mathrm{~mm}$ and $150 \mathrm{~mm}$ sieve.

Total quantities of particle passing through $150 \mathrm{~mm}$ sieve are negligible compared to quantity of other size particles. There for quartz sand of sizes $0.25 \mathrm{~mm}$ (60 meshes), $0.15 \mathrm{~mm}$ (100 mesh) and $0.75 \mathrm{~mm}$ (200mesh) are used to full fill the requirements of very fine particles. The sieve analysis is done by adding different percentage of sieved particles. Number of trial is carried out by varying the percentage of different sieved particles to achieve $S$ curve as per Indian standard. S- Curve obtained is shown in fig 3.1

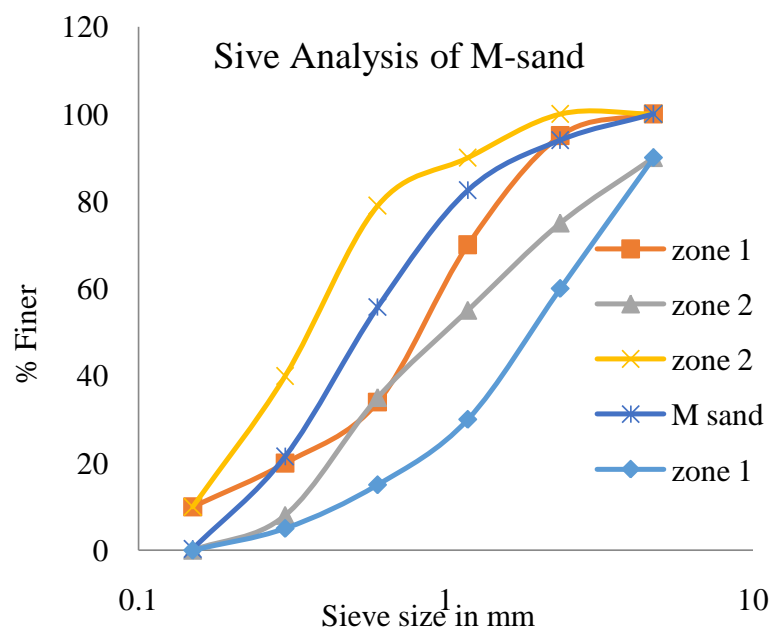

Fig 3.1 Gradation curve $M$ - sand

This experimental study consist 2 mixes. Mix 1 consists only the fine aggregate and mix 2 consist both fine and coarse aggregate. In the both mix $5 \%$ of cement is replaced by metakoaline and $10 \%$ of cement is replaced by microsilica.20\% of M-sand is replaced by quartz sand. Experimental work carried out for different water cement ratio 0.3, 0.26 and 0.22. Mix proportions for Mix 1 and Mix 2 are tabulated in table 3.1 and 3.2 as shown below. 
Table 3.1 Mix Proportion Detail of Mix 1

\begin{tabular}{|l|l|l|}
\hline Materials & \% by Weight & W/c Ratio \\
\hline Cement & 1 & \\
\cline { 1 - 2 } Micro SilicaFume & 0.1 & \multirow{2}{*}{$0.30,0.26}$, \\
\cline { 1 - 2 } $\begin{array}{l}\text { High Reactivity } \\
\text { Metakaolin }\end{array}$ & 0.05 & \\
\cline { 1 - 2 } M-Sand & 1.72 & \\
\cline { 1 - 2 } Coarse Aggregate & - & \\
\cline { 1 - 2 } Quartz Sand & 0.32 & \\
\cline { 1 - 2 } Steel Fibers & 0.00575 & \\
\hline
\end{tabular}

Table 3.2 Mix Proportion Detail of Mix 2

\begin{tabular}{|l|l|l|}
\hline Materials & \% by Weight & W/c Ratio \\
\hline Cement & 1 & \\
\cline { 1 - 2 } Micro Silica Fume & 0.1 & \multirow{2}{*}{$0.30,0.26}$, \\
\cline { 1 - 2 } $\begin{array}{l}\text { High Reactivity } \\
\text { Metakaolin }\end{array}$ & 0.05 & \\
\cline { 1 - 2 } M-Sand & 0.85 & \\
\cline { 1 - 2 } Coarse Aggregate & 0.77 & \\
\cline { 1 - 2 } Quartz Sand & 0.32 & \\
\cline { 1 - 2 } Steel Fibers & 0.00575 & \\
\hline
\end{tabular}

\subsection{Mixing}

The mixing of concrete ingredient is done by using pan mixer of 4 liters capacity. First dry mix is prepared by mixing the aggregates, cement steel fibres and mineral admixture. Dry mixing is carried out for 10 minutes. Then water and superplastisizers are added. Chemical admixture is added by percentage wise. For the each percentage fresh properties are checked as per EFNARC 2005. The mixing is done for different water cement ratio $0.3,0.26$ and 0.22 . For the each water cement fresh properties and modulus of elasticity is determined.

\subsection{Fresh Properties}

The fresh concrete properties such as filling ability, passing ability, and resistance to segregation of the concrete sample are based on the EFNARC 2015. No single test method is available, to determine the fresh properties concrete. There for each mix is tested by different test methods to full fill the fresh concrete properties such slump flow test, V funnel, L box, $\mathrm{U}$ box and $\mathrm{J}$ ring.

\subsubsection{Slump Flow}

This test is helps to determine the slump of a self compacting concrete. This test is used, to assess the fillingability and resistance to segregation of self compacting concrete. In this test slump flow and $T 50 \mathrm{~cm}$ time is determined and results are compared with standard values as per EFNARC 2005

\subsubsection{Box}

This method is suitable to find out the flow ability of concrete and also the passing ability of the concrete in the reinforcement section. The segregation may be detected by the visual inspection of the concrete in the horizontal section. Difference in height between the horizontal sections is computed results are compared with standard values as per EFNARC 2005.

\subsubsection{U Box}

The test method is also called as box shaped test method. This test method helps to determine the filing-ability of SCC.

\subsubsection{Funnel}

This test method helps to determine the filling-ability of the SCC. Time required for the concrete to complete discharge is noted and these results are compared with standard values as per EFNARC 2005.

\subsubsection{J Ring}

This test helps to find out the passing- ability of SCC. These results are compared with standard values as per EFNARC 2005.

\subsection{Casting}

For the modulus of elasticity test $100 \mathrm{~mm}$ diameter and $200 \mathrm{~mm}$ height cylinders are used. After confirming the fresh properties, fresh concrete is poured in to steel cylindrical mould. After 24 hour it is demoulded and kept in water for curing.

\subsection{Curing}

Curing is done by immersing i water. Casted cubes are demoulded after 24 hour and kept in water for 28 days.

\section{RESULTS \& DISCUSION}

\subsection{Paste Content}

The Paste content is the summation of amount of paste required to fill the voids in the concrete mass and $10 \%$ paste extra to coat the aggregate. The paste content of different water binder for both the mix is tabulated in table 4.1.

Table 4.1 Paste Contents of Different Mixes

\begin{tabular}{|l|l|l|}
\hline \multirow{2}{*}{ w/c } & \multicolumn{2}{|l|}{ Paste Content in \% } \\
\cline { 2 - 3 } & Mix 1 & Mix 2 \\
\hline 0.3 & 47.5 & 51.5 \\
\hline 0.26 & 44.8 & 48 \\
\hline 0.22 & 41.35 & 44.7 \\
\hline
\end{tabular}

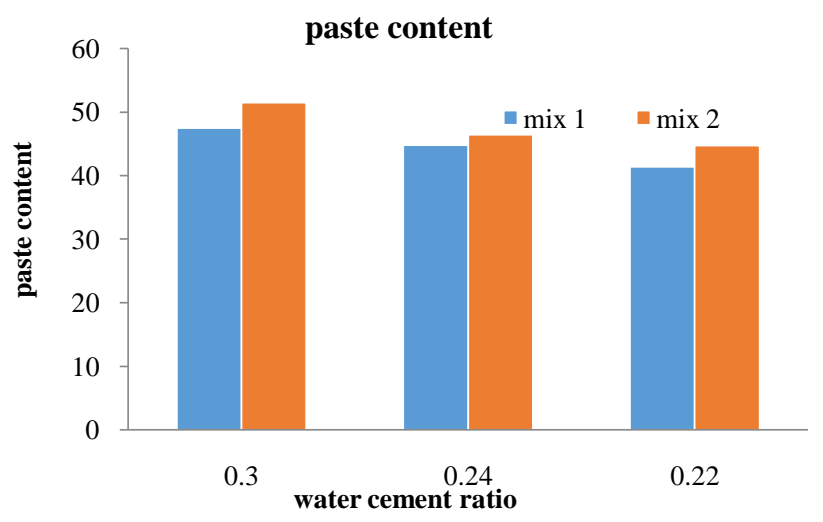

Fig4.1 Variation of Paste Content with Water Cement ratio 


\subsection{Slump Flow}

Confirmation results of slump flow test, for the both the mix is tabulated in table 4.2. results are analyzed graphically.

Table 4.2 Summary of Results Slump flow

\begin{tabular}{|l|l|l|l|l|}
\hline \multicolumn{1}{|c|}{ Water Cement Ratio } & 0.3 & 0.26 & 0.22 \\
\hline \multirow{4}{*}{ Mix 1 } & Paste Content in \% & 47.5 & 44.8 & 41.35 \\
\cline { 2 - 5 } & Admixture Dosage in \% & 0.65 & 0.85 & 1.3 \\
\cline { 2 - 5 } & Horizontal Flow in mm & 780 & 710 & 660 \\
\cline { 2 - 5 } & T50 cm Flow Time in sec & 2 & 3 & 5 \\
\hline \multirow{4}{*}{ Mix 2 } & Paste content in \% & 51.5 & 48 & 44.7 \\
\cline { 2 - 5 } & Admixture Dosage in \% & 0.55 & 0.75 & 1.2 \\
\cline { 2 - 5 } & Horizontal Flow in mm & 760 & 680 & 630 \\
\cline { 2 - 5 } & T50 cm flow Time in sec & 3 & 4 & 5 \\
\hline
\end{tabular}

slump flow result Comparision



Fig 4.2 Variation of Slump Flow with Paste Content

\subsection{J ring}

Confirmation results of $\mathrm{J}$ Ring test, for the both the mix is tabulated in table 4.3. Results are analyzed graphically.

Table 4.3 Summary of Results J Ring

\begin{tabular}{|l|l|l|l|l|}
\hline \multicolumn{2}{|l|}{ Water Cement ratio } & 0.3 & 0.26 & 0.22 \\
\hline \multirow{3}{*}{ Mix1 } & Paste Content in \% & 47.5 & 44.8 & 41.35 \\
\cline { 2 - 5 } & Admixture Dosage in \% & 0.65 & 0.85 & 1.3 \\
\cline { 2 - 5 } & $\mathrm{T}_{50}$ cm Flow in sec & 4 & 6 & 8 \\
\hline \multirow{3}{*}{ Mix 2 } & Paste Content in \% & 51.7 & 48 & 44.7 \\
\cline { 2 - 5 } & Admixture Dosage in \% & 0.55 & 0.75 & 1.2 \\
\cline { 2 - 5 } & $\mathrm{T}_{50}$ cm Flow in sec & 5 & 8 & 10 \\
\hline
\end{tabular}

\section{J Ring Flow result Comparision}

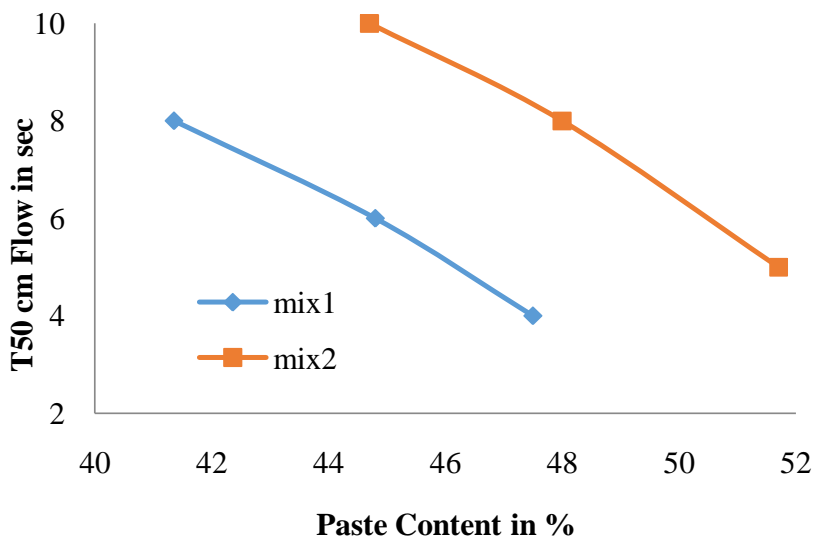

Fig 4.3 Variation of J Ring with Paste Content

\subsection{Box}

Confirmation results of $\mathrm{L}$ box test, for the both the mix is tabulated in table 4.4 .

Table 4.4 Summary of Results L Box

\begin{tabular}{|l|l|l|l|l|}
\hline \multicolumn{2}{|l|}{ Water Cement Ratio } & 0.3 & 0.26 & 0.22 \\
\hline \multirow{4}{*}{$\begin{array}{l}\text { Mix } \\
1\end{array}$} & Paste Content in \% & 47.5 & 44.8 & 41.35 \\
\cline { 2 - 5 } & Admixture Dosage in \% & 0.65 & 0.85 & 1.3 \\
\cline { 2 - 5 } & Blocking Ratio $\left(\mathrm{H}_{2} / \mathrm{H}_{1}\right)$ & 0.95 & 0.9 & 0.85 \\
\hline \multirow{2}{*}{\begin{tabular}{l} 
Mix 2 \\
\cline { 2 - 5 }
\end{tabular}} & Paste Content in \% & 51.7 & 48 & 44.7 \\
\cline { 2 - 5 } & Admixture Dosage in \% & 0.55 & 0.75 & 1.2 \\
\cline { 2 - 5 } & Blocking Ratio $\left(\mathrm{H}_{2} / \mathrm{H}_{1}\right)$ & 0.9 & 0.85 & 0.85 \\
\hline
\end{tabular}

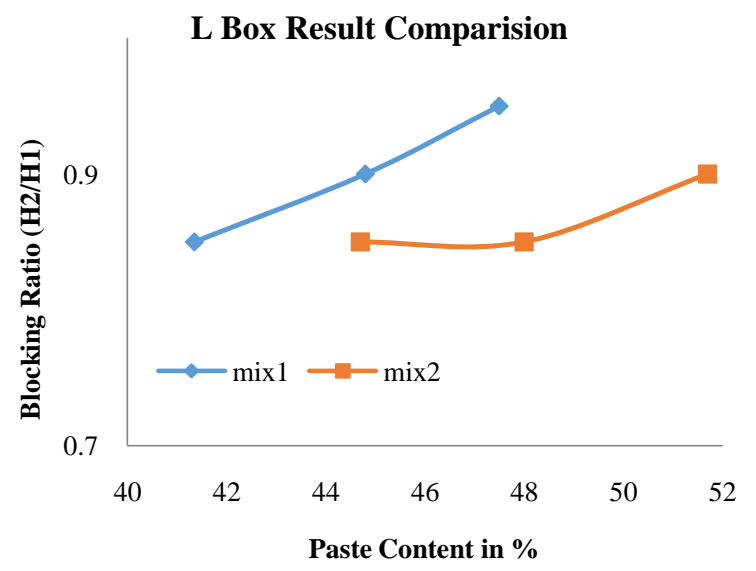

Fig4.4 Variation of Blocking Ratio with Paste Content

\subsection{Funnel}

Confirmation results of $\mathrm{v}$ funnel test, for the both the mix is tabulated in table 4.5. 
Table 4.5 Summary of Results V Funnel

\begin{tabular}{|l|l|l|l|l|}
\hline \multicolumn{2}{|c|}{} & 0.3 & 0.26 & 0.22 \\
\hline \multirow{4}{*}{ Mix 1 } & Paste Content in \% & 47.5 & 44.8 & 41.35 \\
\cline { 2 - 5 } & Admixture Dosage in \% & 0.65 & 0.85 & 1.3 \\
\cline { 2 - 5 } & Tr - Flow Time in sec & 9 & 10 & 11 \\
\cline { 2 - 5 } & Flow at T5 min in sec & 8 & 10 & 12 \\
\hline \multirow{4}{*}{ Mix 2 } & Paste content in \% & 51.5 & 48 & 44.7 \\
\cline { 2 - 5 } & Admixture Dosage in \% & 0.55 & 0.75 & 1.2 \\
\cline { 2 - 5 } & Tr - Flow Time in sec & 9 & 11 & 12 \\
\cline { 2 - 5 } & Flow at T5 min in sec & 10 & 13 & 15 \\
\hline
\end{tabular}

\section{Funnel Result Comparision}

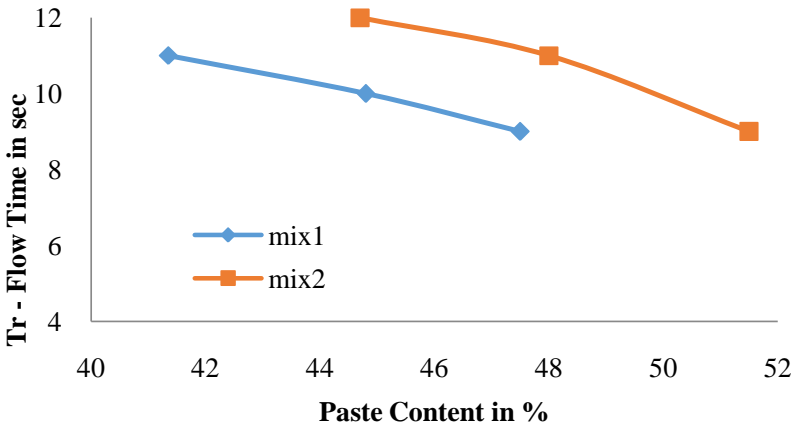

Fig 4.5 Variation of Tr Flow Time with Paste Content

\subsection{Compressive Strength}

The compressive strength of the ultra high performance concrete is evaluated as per IS516.The strength is assessed after 3 days and 28 days of curing. The specimens of compressive strength test of $100 \times 100 \times 100 \mathrm{~mm}$ cubes. Results are tabulated in table 4.6.

Table 4.6 Results of Compressive strength

\begin{tabular}{|l|l|l|l|l|}
\hline \multicolumn{2}{|l|}{ Water Cement Ratio } & 0.3 & 0.26 & 0.22 \\
\hline \multirow{3}{*}{$\begin{array}{l}\text { Mix } \\
1\end{array}$} & Paste Content \% & 47.5 & 44.8 & 41.3 \\
\cline { 2 - 5 } & 3days Strength in MPa & 47.55 & 57.26 & 66.23 \\
\cline { 2 - 5 } & 28 day & 100.1 & 111.83 & 119.5 \\
\hline \multirow{2}{*}{$\begin{array}{l}\text { Mix } \\
2\end{array}$} & Paste Content \% & 51.5 & 48 & 44.7 \\
\cline { 2 - 5 } & 3days Strength in MPa & 44.62 & 54.62 & 61.54 \\
\cline { 2 - 5 } & 28 day & 89.5 & 97.23 & 105.36 \\
\hline
\end{tabular}

28 day compressive strength

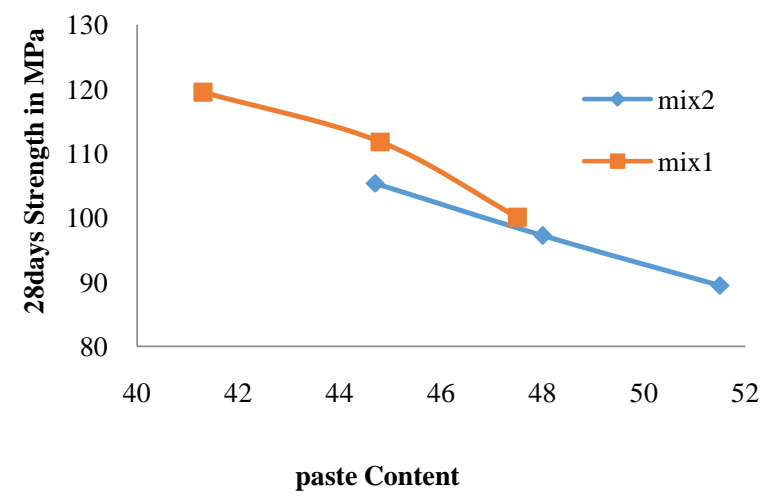

Fig 4.6 28 Day Compressive Strength

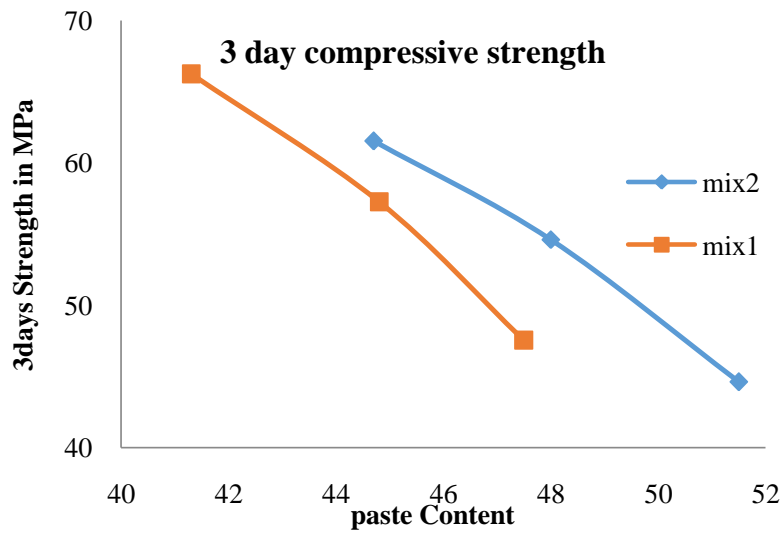

Fig 4.7. 3 Day Compressive Strength

\section{OBSERVATIONS \& CONCLUSIONS}

- The Mix2 with coarse aggregates shows higher paste content than the mixes without coarse aggregates, indicating the presence of higher void content of mix2 created due to the presence of coarse aggregates. This shows that, the concrete mixes with coarse aggregates need more volume of paste (higher paste content) than that without aggregates.

- The paste content of the mixes decreases with reduction in the water cement ratio.

- Flow properties of UHPC mixes can be improved with increase in paste volume of the mix. The reduced flow may be attributed to the presence of coarse aggregates as well as resulting reduction in the volume of paste.

- The Rheology of mixes measured in using tests on Slump, L-Box, V-Funnel Test and U Box can be achieved by varying the admixture. The mixes without coarse aggregates show better behaviour in fresh state than that with coarse aggregates

- The strength of UHPC mixes is more without coarse aggregates than with coarse aggregates at higher cementitious content

- The compressive strength of $100 \mathrm{~N} / \mathrm{mm}^{2}$ to 119.5 $\mathrm{N} / \mathrm{mm}^{2}$ can be achieved for a curing period of 28 days for the mix without coarse aggregates. However, the strength for the same mix with coarse aggregates ranges from $89.5 \mathrm{~N} / \mathrm{mm}^{2}$ to $105.3 \mathrm{~N} / \mathrm{mm}^{2}$.

\section{REFERENCES}

[1] Adel A. Al-Azzawi, Ahmed Sultan Ali and Husam K Risan, Behavior of Ultra High Performance Concrete Structures: ARPN Journal of Enginnering and Applied Science, Vol 6, No 5, May 2011, ISSN 18196608.

[2] Asma K C, Meera C M, Preetha Prabhakaran, Effect of Mineral Admixtures on Durability Properties of High Performance Concrete: International Journal of Engineering Research and Applications (IJERA), pp33-37, ISSN: 2249-6645, (TRACE-24 $4^{\mathrm{TH}}-25^{\mathrm{TH}}$ January 2014).

[3] B B Patil, P D Kumbhar, Strength and Durability Properties of High Performance Concrete Incorporating High Reactivity Metakaolin: 
International Journal of Modern Engineering Research (IJMER), Vol 2, Issue 3, May- June 2012 pp- 1099-1104, ISSN: 2249-6645.

[4] Doo-Yeol Yoo a, Su-Tae Kang b , Young-Soo Yoon c, Enhancing the flexural performance of ultra-highperformance concrete using long steel fibers, Composite Structures 147 (2016) 220-230, Science Direct, 17 March 2016.

[5] Dr. S Sundararaman, S Azhagarsamy; Performance of Ultra High Performance Concrete Containing Mineral Admixtures: SSRG International journal of Civil Engineering Vol: 2, Issue 10, October 2015.

[6] M. Al -Hassani, 2. W. I. Khalil, 3. L. S. Danha, Acta Tehnica Corviniensis, Mechanical Properties of Reactive Powder Concrete with Various Steel Fiber and Silica Fume Contents: - Bulletin of Engineering, Tome VII [2014], Fascicule 1 [January - March] ISSN: 2067 - 3809.

[7] Jianxin Ma, Marko Orgass, Comparative Investigations on Ultra-High Performance Concrete with and without Coarse Aggregates: Kassel, Germany September 2004.

[8] M. Dayanand1 , K.Rajasekhar, A Study Of High Strength Fibre Reinforced Concrete By Partial Replacement Of Cement With Silica Fume And Metakaolin: International Journal of Advanced Technology in Engineering and Science www.ijates.com Volume No.03, Issue No. 05, May 2015 ISSN (online): 2348 - 7550.

[9] Nagesh N Meleka, Alaa A Bashandy, Mohamed A Arab, Ultra High Strength Concrete Using Economical Materials: International Journal Of Current Engineering And Technology (IJCET), ISSN 2277-4106, Volume 3, No 2, June 2013.

[10] Narasimha Raj, Suresh G Patil and B. Bhattacharjee, Concrete Mix Design By Packing Density Method: IOSR Journal of Mechanical and Civil Engineering (IOSR-JMCE) e-ISSN: 2278-1684,p-ISSN: 2320334X, Volume 11, Issue 2 Ver. I (Mar- Apr. 2014), PP 34-46.

[11] Prabhat Rajan Prem, B H Bharatkumar, Nagesh R Iyer, Mechanical Properties of Ultra High Performance Concrete: International journal of Civil, Environmental, Structural, Construction and Architectural Engineering Vol: 6, No 8, 2012.

[12] R R Yu, P Spiesz, H J H Brouwers, Mix design and properties assessment of Ultra High Performance Fiber Reinforced Concrete: Cement and Concrete Research, 56(2014) 29-39.

[13] Manoj V, Shiva Kumar K S, Santhosh K Behaviour of Mechanical Properties Ultra High Performance Concrete With Steel Fibres and Mineral Admixtures IJRET: International Journal of Research In Engineering And Technology, volume:05, issue: 09, pg-299-305

\section{BIOGRAPHIES}

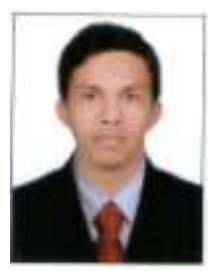

SANTHOSH K, M.Tech in Civil Structural Engineering, P G Student, Global Academy of Technology Santhoshknayak135@gmail.com

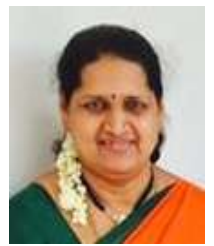

SAVITHRI KARANTH, M.Tech in Civil Structural Engineering, Assistant Professor, Global Academy of Technology



MANOJ V, M.Tech in Civil Structural Engineering, P G Student, Global Academy of Technology Manojvconcrete90@gmail.com 